\title{
LANDSCAPES WITH DIFFERENT LOGICS: A PHYSICALISTIC APPROACH TO SEMANTIC CONFLICTS IN SPATIAL PLANNING
}

\author{
Robert Krzysztofik ${ }^{1}$, Mirek Dymitrow ${ }^{2}$, Jadwiga Biegańska ${ }^{3}$, Adam Senetra ${ }^{4}$, \\ Eleftheria Gavrillidou ${ }^{5}$, Bogdan Nadolu ${ }^{6}$, Iwona Kantor-Pietraga ${ }^{7}$, \\ Elżbieta Grzelak-Kostulska ${ }^{8}$, Eleni Oureilidou ${ }^{9}$, Daniel Luches $^{10}$, Tomasz Spórna ${ }^{11}$, \\ Dominic TeOdorescu ${ }^{12}$, Monika Wasilewicz-PszczóŁKowsKa ${ }^{13}$, Gun Holmertz ${ }^{14}$, \\ AgNiesZKa SZCZEPAŃSKA ${ }^{15}$, RenÉ Brauer ${ }^{16}$
}

\begin{abstract}
${ }^{1}$ University of Silesia, Faculty of Earth Sciences, Department of Economic Geography, Sosnowiec, Poland ${ }^{2}$ University of Gothenburg, School of Business, Economics and Laws, Department of Economy and Society Unit for Human Geography, Göteborg, Sweden

${ }^{3}$ Nicolaus Copernicus University in Torun, Department of Urban Studies and Regional Development, Torun, Poland

${ }^{4}$ University of Warmia and Mazury in Olsztyn, Department of Planning and Spatial Engineering, Olsztyn, Poland

${ }^{5}$ Aristotle University of Thessaloniki, School of Architecture \& School of Agriculture, Joint Postgraduate

Programme Landscape Architecture, School of Architecture \& School of Agriculture, Thessaloniki, Greece

${ }^{6}$ West University of Timişoara, Department of Sociology, Timişoara, Romania

${ }^{7}$ University of Silesia, Faculty of Earth Sciences, Department of Economic Geography, Sosnowiec, Poland ${ }^{8}$ Nicolaus Copernicus University in Torun, Department of Urban Studies and Regional Development, Torun, Poland

${ }^{9}$ Aristotle University of Thessaloniki, School of Architecture \& School of Agriculture, Joint Postgraduate Programme Landscape Architecture, Thessaloniki, Greece

${ }^{10}$ West University of Timişoara, Department of Sociology, Timişoara, Romania

${ }^{11}$ University of Silesia, Faculty of Earth Sciences, Department of Economic Geography, Sosnowiec, Poland ${ }^{12}$ University of Uppsala, Department of Social and Economic Geography, Ekonomikum, Uppsala, Sweden

${ }^{13}$ University of Warmia and Mazury in Olsztyn, Department of Planning and Spatial Engineering, Olsztyn, Poland

${ }^{14}$ Caritas Sweden Göteborg, Volunteer Central Angered, Angered, Sweden

${ }^{15}$ University of Warmia and Mazury in Olsztyn, Department of Planning and Spatial Engineering, Olsztyn, Poland
\end{abstract}

${ }^{16}$ René Brauer University of Surrey, Faculty of Arts and Social Sciences; School of Hospitality and Tourism Management, Guildford, Surrey, United Kingdom

Manuscript received: January 31, 2016

Revised version: July 7, 2016

Krzysztofik R., Dymitrow M., Biegańska J., Senetra A., Gavrillidou E., Nadolu B., Kantor-Pietraga I., Grzelak-Kostulska E., Oureilidou E., Luches D., Spórna T., Teodorescu D., Wasilewicz-PszczóŁKowska M., Holmertz G., Szczepańska A., BRAUER R., 2017. Landscapes with different logics: A physicalistic approach to semantic conflicts in spatial planning. Quaestiones Geographicae 36(4), Bogucki Wydawnictwo Naukowe, Poznań, pp. 29-45, 1 table, 7 figs. 
AвSTRACT: This paper deals with the ways of categorising landscapes as 'urban' and 'rural' using a physicalist approach, where these terms have special meaning. The aim of this paper is to elaborate on the question whether such a division is still meaningful with regard to anthropogenic landscapes, not least in spatial planning. The concerns raised in this paper depart from the increasingly complicated structure of geographical space, including that of anthropogenic landscapes. Our standpoint is illustrated using cases of landscape ambiguities from Poland, Germany, Romania and Greece. Leaning on frameworks of physicalist (mechanicistic) theory, this paper suggests an explanation to the outlined semantic conflicts. This is done by pointing to the relationality between the impact of centripetal and centrifugal forces, the specifics of socio-economic development, as well as the varying landscape forms that emerge from the differences within that development.

KEY WORDS: urban landscapes, rural landscapes, semantics, physicalist approach, spatial planning

Corresponding author: Robert Krzysztofik, University of Silesia, Faculty of Earth Sciences, Department of Economic Geography, 60 Będzińska Str., Sosnowiec, 41-200, Poland, robert_krzysztofik@interia.pl

\section{Introduction}

As a result of ongoing rapid societal transformations, most notably urbanisation, the traditional division of landscapes into "rural" and "urban" is becoming decreasingly clear-cut. Throughout the developed world, areas classified traditionally as 'rural' are in constant socio-economic and visible transition. With the resource-based economy in decline in favour of greater economic diversity, the countryside of today "has shifted from being a landscape of production to also being a landscape of consumption" (Dymitrow, Stenseke 2016). Increased personal mobility, telecommunications and information technology have all rendered the countryside a functional extension of the city (Millward et al. 2003). Indeed, since the $19^{\text {th }}$ century, urbanised localities in many European countries have outnumbered formally designated cities. In this view, the very concept of 'village' raises doubts

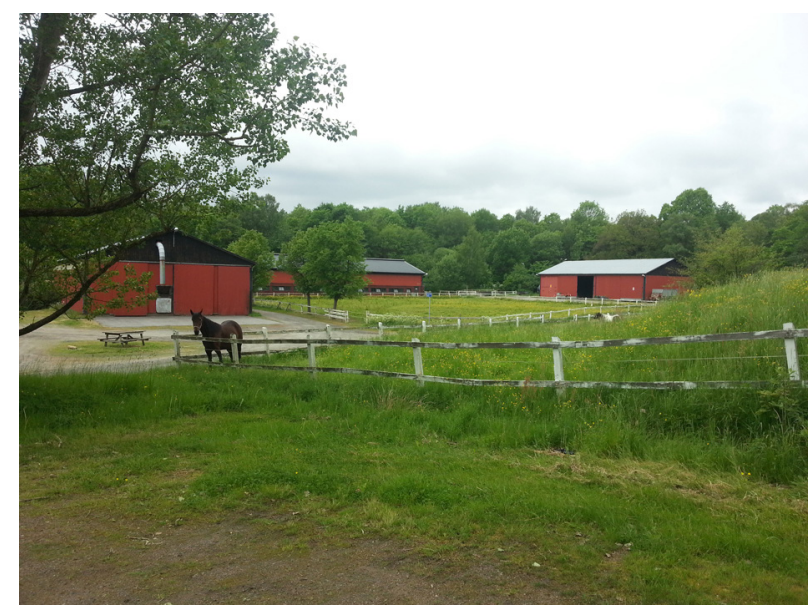

Fig. 1. "Ruralisation" of the urban landscape in Gothenburg (Sweden) for social purposes. Source: the authors. in that agricultural structures have become enmeshed with social aspects of urbanisation (Fig. 1). Instances of rural-urban blurring have been represented through phenomena such as disserviced housing estates, brownfield villages, flophouses, residential trailer parks, shantytowns, favelas, tent cities, degraded towns, hibernated towns, etc. (Dymitrow et al. 2017; Vaishar et al. 2016; Connell 2016; Nefedova, Pallot 2013), but also through the introduction of urban agriculture in large cities around the globe (Antrop 2004b; Deng et al. 2009; Tornaghi 2014; Mazzochi et al. 2013; Wu et al. 2013; Dymitrow 2013, 2014; Krzysztofik et al. 2016; Cavallo et al. 2016; Prové et al. 2016). Effectively, many settlement forms today structured around the concepts of "urbanity" and "rurality"' respectively, also have an embedded element of the opposite binary concept.

Still, although 'rural' and 'urban' today should perhaps best be understood as 'categories of thought', 'narratives', or 'conversational realities', they continue to underpin large sectors of societal organisation as acceptable guiding perspectives (Tunström, Spas 2017; Dymitrow, Brauer 2016; Somerville et al. 2014; Brenner 2013; Ulied et al. 2010; Woods 2010; Halfacree 1993, 2009; Cloke, Johnston 2005; Ward, Brown 2009; Taylor 2007; Hubbard 2006; Champion, Hugo 2004; Millward et al. 2003; Moseley 2003; Mormont 1990; Hoggart 1990). The point is that due to increasing rural-urban blurring and the lack of satisfactory working definitions, there is an ever greater likelihood that a separate treatment of "rural" and "urban" in policy and planning may get in the way of making informed analyses and sound development decisions. 
These instances give rise to an intriguing question: is the division of anthropogenic landscapes into "rural" and "urban" still acceptable or does it merely represent sketchy border points among many other spatial characterisations of human space? The aim of this article is to attempt to elaborate on this question experimentally using a physicalist (mechanicistic) approach that builds on the notions of centrifugal and centripetal forces. In philosophy, physicalism is the ontological thesis claiming that everything in the world is physical and that everything supervenes on the physical (Smart 1959). Physicalism, hence, is a form of ontological monism, i.e. a one-substance view of the nature of reality (as opposed to, e.g. dualism, pluralism, and so on - Berger and Luckmann 1966). In this context, we focus specifically on the most basic conditions adding to the vulnerability of the notions of "urban" and "rural" with regard to the causal mechanisms shaping the anthropogenic landscape. The contribution of this paper lies in the unification of different ontological frameworks. The theoretical point this article is aiming to crystallise is that human beings influence the 'landscape' in more ways than just creating and maintaining it. We concede that the physicalist approach represents such a framework.

Such an angle of attack subscribes to the post-positivist paradigm, assuming an objective reality, but conceding that it can only be apprehended imperfectly and probabilistically. In our view, epistemological commitment to anthropogenic landscapes is that of a modified dualist/ objectivist way of knowing, focusing methodologically on the falsification of generally accepted statements or hypotheses (Lincoln et al. 2011). Realising that all scientific paradigms (from positivism to constructivism) are human constructions, they are subject to human error. As Guba and Lincoln (1994: 108) argue, "[n]o construction is or can be incontrovertibly right [while] advocates of any particular construction must rely on persuasiveness and utility rather than proof in arguing their position".

In that view, seeing current landscape research dominated by constructivist, relativist, subjectivist, transactionalist and feminist perspectives comes across as cumbersome (Cosgrove 1984; Daniels 1989; Rose 1993; Olwig 1996; Duncan, Duncan 2001; Mitchell 2002;
Henderson 2003; Gobster et al. 2007; Wylie 2007; Mels, Germundsson 2013). This in spite of Hartshorne's (1939) early critique of the landscape concept's questionable role in scientific geography due to its incorporation of subjective elements. When it comes to conceptualisations of 'landscape' there is of course a manifold of scientific perspectives, none of which is inherently better or worse. 'Landscape' has been a cardinal term of human geography that has served as a "central object of investigation, organising principle and interpretive lens for several different generations of researchers". Although its popularity has both ascended and waned through times, the constancy of a landscape seems to lie in its function as "a locus for geographical research into culture-nature and subject-object relations" (Gregory et al. 2009: 409). To avert the current dominance of discursive, iconographic and interpretive approaches to "landscape", in this paper, for purposes of variety and polyvocality, we retrovert to its Sauerian definition - namely the landscape as a cultural entity produced through interactions between people and topography (Sauer 1925) - but expand it by way of physicalist perspectives.

In line with the definition by Hubbard et al. (2002) of a geographic theory as "an attempt to think space in a new manner", this multi-authored contribution merges perspectives of scholars from five countries, representing different paradigms, epistemic practices and personal convictions (Brauer, Dymitrow 2017), who by ways of negotiation and consensus agreed - under post-positivim's banner - to mold an alternative idea about the nature of anthropogenic landscapes when seen through a rural/urban lens ${ }^{1}$. Such

\footnotetext{
This article is the effect of theoretical discussions and philosophical deliberations in the wake of a special session held at the 2014 PECSRL conference (Biegańska et al. 2014), to the fore of which were brought analyses of rural landscapes endowed with specific urban traits of broadly understood "dysfunctionality". The aim of the session was to unravel the logics of these particular landscapes by means of: (1) the cognition of the factors and mechanisms that contributed to their emergence; (2) the analyses of the processes that take place in them in order to: (a) determine their course and dynamics, (b) establish potential directions for change; (c) propose methodological solutions for doing research; (3) generalisation of research results in search of similarities in order to: (a) formulate universal methodological assumptions, (b) marshal solutions useful for decision-making at administrative
} 
an approach aims to contribute to the bridging of chasms between different ontological conceptualisations of the same 'rural' or 'urban' space. As such, the proposed physicalist approach can be seen as counterpoint to common postmodern conceptualisations, which only sparingly address the complementarity of phenomena in-between the genetic background of landscapes and the final structured effect. In our opinion, a physicalist approach with functionalist elements has the potential to cover this gap, and possibly provides more clarity to the conflicting theories on how landscapes can be read and understood in times when 'rural' and 'urban' are losing their explanatory power.

\section{Theoretical and methodological assumptions}

Taking into account the above-mentioned assumptions and referring to the preliminary hypotheses of the article, we adopted the physicalist approach in the so-called Newtonian mechanicism convention (Knudsen, Hjorth 1996) as the basis for our explanations. This convention relates to the impact of the centripetal and centrifugal forces in geographical space (Krugman 1995, Fujita 2012). The said approach contains an attribute which is by nature lacking in other approaches. Owing primarily to the clear schematism of the sense of forces affecting space,

and institutional levels. The session has attracted 10 presentations, including: [1] post-war rural areas in Amsterdam (Abrahamse J.E.); [2] Zagreb's peri-urban fringe (Toskić A., Njegač D. \& Orešić D.); [3] rural transformation from urban influences in Olsztyn (Wasilewicz-Pszczółkowska M., Szczepańska A. \& Senetra A.); [4] degraded urban agglomerations in Poland (Krzysztofik R., Kantor-Pietraga I. \& Spórna $\mathrm{T}$.); [5] landscapes transcending rural-urban characteristics in Gothenburg (Dymitrow M., Brauer R., Holmertz G., Apostolovska-Toševska B., Holmberg F. \& Johansson L.); [6] landscape discriminants in the valorisation of rural areas in Poland (Bocheńska-Skałecka A., Kuriata Z., Niedźwiecka-Filipiak I., Podolska A. \& Serafin L.); [7] degraded towns in Silesia (Szmytkie R.); [8] agri-ghettos in central Poland (Biegańska J., Grzelak-Kostulska E. \& Dymitrow M.); [9] Bucharest's Romani ghetto (Teodorescu D.); and [10] urban agriculture in socially deprived areas of Thessaloniki (Gavriilidou E., Dedousi D., Oureilidou E. \& Ritou M.). mechanicism is a particular filter that separates primary phenomena and structures from secondary ones. In mechanicism, they are accompanied by the features of an apparent reality, or apparentness. The concept of "apparent reality" implies that we can only derive sense from the following path: (1) sensory input $>>$ (2) hypothesis of realness $>>$ (3) test $>>$ (4) consensus formation $>>(5)$ update of consensus to accommodate new insights. The basic premise is that the notion of reality can only consolidate once observation (sensory input) has occurred ${ }^{2}$. As such, what we understand as "reality" is inherently apparent (Jaynes 2003). Therefore, in landscape research the concept of apparentness may come to constitute a tool that can help resolve problems of interpretation, especially with regard to explanations revolving around concepts as semantically general as "urban landscape" and "rural landscape".

The physicalist approach, along with the systemic approach and the approach resulting from the Gestalt theory, is among the most common (Richling, Solon 2011). As part of the physicalist approach, we proposed the aspect of the mechanicism of spatial research which manifests itself in the roles of the centripetal and centrifugal forces affecting geographic space and the anthropogenic landscape. We treated the impact of centripetal and centrifugal forces as a direct stimulator of economic and social processes in geographic space and the anthropogenic landscape (Krugman 1995, Fujita et al. 2001, Olsen 2002). As we have already mentioned, the mechanicist approach draws attention to the fundamental geographic basis for the creation of landscapes ${ }^{3}$. Therefore, in each case when it is taken into account, it increases the chances for an accurate

2 In contrast, "absolute reality" implies that reality exists irrespective of the observer and that our notion of reality is governed by our bodily limitations to sense it.

3 In the socio-economic (anthropogenic) and natural systems, there are two main forces shaping "reality" (processes, phenomena, structures): centripetal forces and centrifugal forces. These forces have been accepted in the literature as metaphors, although they do not fully meet the criterion of a metaphor (inter alia because of the different trajectories of motion). In reality, they represent the forces of gravity and recoil. Nevertheless, they are called centripetal and centrifugal forces in the geographic literature, especially within the new economic geography (Krugman 1995). 
interpretation of the landscape in terms of such elements as:

- the genetic background of the landscape;

- key mechanisms of its evolution;

- the distinction between genuinely and apparently material factors.

Centripetal and centrifugal forces are thus also fundamental attributes for the formation of the settlement systems, because we assume that urban and rural landscapes are a visual image and a direct reflection of those systems in geographic space. This belief is strengthened by the fact that the notions of rurality and urbanity are primarily of a functional and economic nature (Bański 2006; Johansen, Nielsen 2012). Simplistically, the rural landscape in its model form is a landscape type which was formed and is shaped by the agriculture sector ${ }^{4}$. On the other hand, the urban landscape is a landscape type which was formed and shaped by the industrial, mining, service and trade functions (Martin, Sunley 2012). However, the above-mentioned assumptions determine only the relations between the physiographic and functionalist approaches in landscape research. It remains to clarify the relations between the functionalist and the physicalist approach (mechanistic in this specific case). This issue was already discussed by, e.g. Krugman (1995), Fujita et al. (2001), Fujita, Thisse (2002) and Krzysztofik $(2014,2016)$. In the most general terms, this relation may be brought down to the following dependencies and statements:

\footnotetext{
As primary centrifugal forces we distinguish activities such as agriculture, often in combination with farming, horticulture or logging, but also those military or mining activities that are physically bound to a particular location. For example, try framing on Mt. Everest, mine for gold in a depleted mine or militarily defend an open plane. The features of such activities are shaped by material 'forces' (affordances). Secondary centripetal forces, on the other hand, may involve centrifugal forces, but are not vital for their functionality. For example, trade on a river is faster than going by foot, but with the invention of motor transport such a separation shifts. The same applies for administrative borders, for example, a particular geographical feature (a mountain range, a river, a valley etc.) may be used as a border but this does not imply that the border will remain in this location. In conclusion, the reason for employing such a dual distinction in this article is to conceptualise cultural constructs as part of the 'forces' that shape the material world.
}

- agricultural and military functions are developed by centrifugal forces,

- extremely specialised functions: mining, industry, certain types of transport and services (e.g. tourist services) are developed by centrifugal forces,

- trade and local services are developed by centripetal forces,

- administrative functions are developed by centripetal forces.

In the light of the foregoing, we can conclude that from the physicalist point of view the rural landscape is monogenetic (the rural landscape is shaped by agricultural functions which are a result exclusively of the impact of centrifugal forces), and the urban landscape is polygenetic (the urban landscape is shaped by different functions which are or may be a result of the impact of both centripetal and centrifugal forces). The issue regarding the impact of centripetal and centrifugal forces on the settlement system and, de facto, the anthropogenic landscape in accordance with the model described above was clarified by P. Krugman (1995: 243). If we treat the above-mentioned explanations as a theoretical basis for deliberations concerning the anthropogenic landscape from the post-positivist ontological (hereinafter simplified as ontological) perspective, we can assume that whether a given landscape type exists in a given area depends not only on the type of force which affects the area, but also on the volume of elements forming components of the landscape which are moved by that force. This feature is primarily responsible for the division of urban landscapes into metropolitan, urban and small-town landscapes, and rural landscapes into those describing intensive and extensive agriculture, including forestry.

By its very nature, the mechanistic approach to explaining the conditions for the formation of landscapes and their variation draws attention to some of their features, both at the level of definition and planning. We give special attention primarily to such phenomena as the "apparentness" of the landscape ${ }^{5}$ and the resultant blurring of nomologically modelled landscapes - the urban and the rural (Woods 2009). This issue is equally

\footnotetext{
The attribute of apparentness of the analysed reality is present only in the mechanistic approach because it is the only one to assume the existence of so-called non-inertial frames, in which an image is or may be apparent.
} 


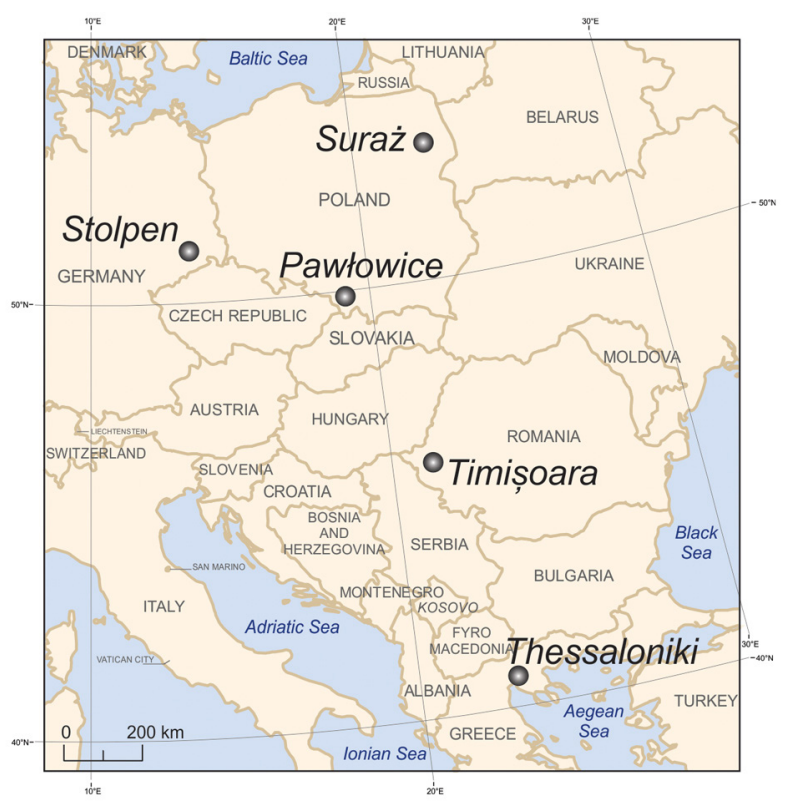

Fig. 2. Case studies on the map of Europe. Source: the authors.

important in defining landscapes and in spatial planning (Masuda, Gavin 2008; Bossuet 2006; Smithers et al. 2005; Walker, Fortmann 2003), as any mistakes perpetuate the stagnation of poorly developing regions and may undermine the growth of those which to date have been growing rapidly. Such categorical statements in landscape studies are not always a goal in itself. However, we should assume that in terms of perception, the anthropogenic landscape is more advantageous where we come across development and not stagnation or socio-economic regress.

The empirical research for this article was synthesised to the form of case studies of five localities and their surroundings: Stolpen in Germany, Pawłowice and Suraż in Poland, Thessaloniki in Greece and Timisoara in Romania (Fig. 2). These case studies represent localities deliberated at a special session (Biegańska et al. 2017; see footnote 1) at the 26th Permanent European Conference on the Study of the Rural Landscape (PECSRL). During our deliberations, we discovered that many cases exhibited similar patterns regardless of the contextual setting (Northern, Central, Eastern and Southern Europe). Furthermore, these patterns also transcended ontological frameworks and associated theories, as they all seemed to describe similar human behavior patterns in relation to the physical aspect of human reality.

Mindful of the often encountered lack of clear methodological guidelines in many conceptual papers, this paper follows the protocols for conceptual research as outlined by Xin et al. (2013) and Tribe and Liburd (2016). More specifically, this is done by way of illustrative rhetorical techniques (especially metaphors), assembled to articulate the (il)logic embedded in commonplace conceptualisations of rural/urban with regard to the concept of landscape.

\section{Apparentness as a feature of the landscape}

Among many attributes of the notion of the landscape we can also find those which are per se its original features. One of those attributes in landscape studies is the apparentness of the landscape which depends on its subjective assessment (Tveit et al. 2006).

Apart from landscape and architectural studies, virtually no other discipline determining the character of geographical space contemplates apparentness determined by the subjectivity of assessments of the experienced space. However, it is of great importance in the economic policy, in particular in that based on the explanations proposed by R. Skidelsky within the framework of Keynesianism (Friedman et al. 2015).

\section{Physiognomic apparentness in the landscape}

At the epistemological level, the feature of apparentness is explained by individual perception and the subjectivism of assessments as the key attributes of landscape studies (Antrop 2004a; de Groot 2006; Drexler 2013). The perceptibility of the landscape appears at least at two levels. Firstly, the landscape manifests itself, and secondly, it is individually (personally) interpreted (Jones, Stenseke 2011). Brabyn (2009: 300) develops this stance further claiming that: "The classification of landscapes is complicated by the fact that it involves both human perception and physical reality, while many of the science classifications tend to be based on just the physical".

Due to such reality cognition frame, the perception of the material layer of the landscape may be and is diverse. If this is true, the apparentness of an anthropogenic landscape must be an attribute of this diversity. This apparentness may be observed from at least two perspectives. In the 


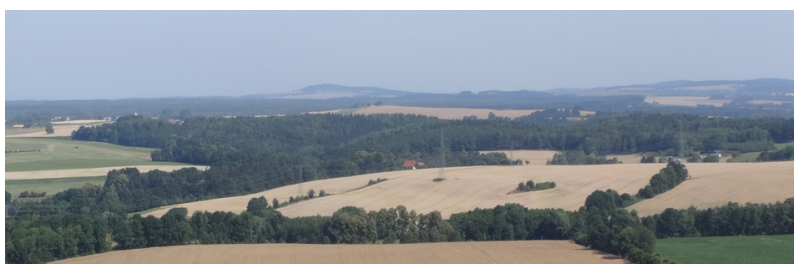

Fig. 3a. Typical landscape of the surroundings of Stolpen (Germany). Dominant features of a "rural landscape".

Source: the authors.

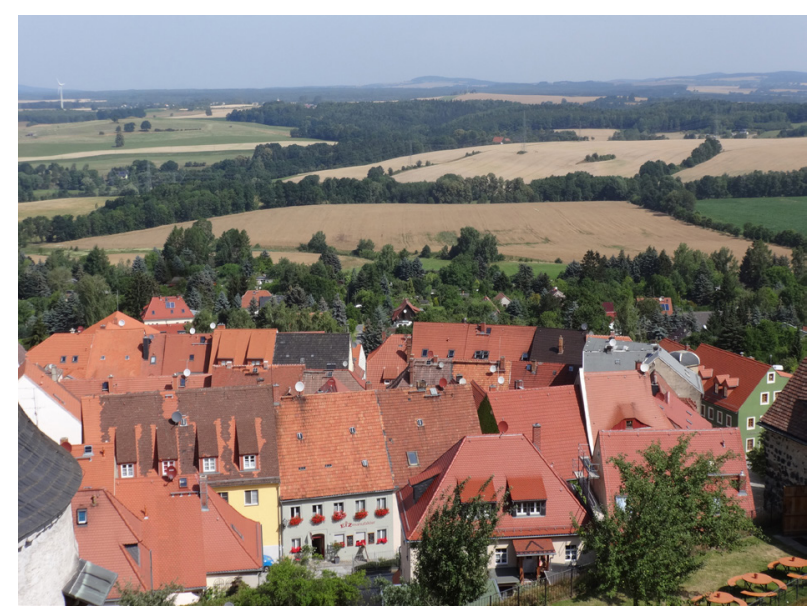

Fig. 3b. Typical landscape of the surroundings of Stolpen (Germany). Mixed "rural-urban landscape". Source: the authors.

first case, what constitutes apparent perception is the landscape range and the borders of its components. The perceived landscape depends on the location of the observer, possibilities, conditions and limitations, and the observations made. In the second case, apparentness results from the structures of components of the anthropogenic landscape: we can have different interpretations of the purpose, functions or morphology of the observed landscape elements. Both approaches are clearly visible in photographs in Figures 3a and $3 \mathrm{~b}$. They present the surroundings of Stolpen in Saxony (Germany) seen from the tower of the castle located in the city. The first shot presents the rural landscape type, while the second one the rural and urban landscape types.

\section{Physicalist background of landscape apparentness}

The apparentness in the anthropogenic landscape, identified above, does not explain the examined reality from the mechanistic perspective. We associate this perspective with the impact of centripetal and centrifugal forces referred to in the previous chapter. To sum up, there are two types of forces operating in the geographical space and the anthropogenic landscape:

- forces of gravity and recoil which are metaphorically described in some publications as centripetal and centrifugal (real and primary forces),

- centripetal and centrifugal forces (apparent and secondary forces).

The question which remains is: how do the above-mentioned theoretical assumptions translate into the discourse regarding geographical reality? For example, with regard to the presented case of the surroundings of Stolpen, this translation is manifold.

Firstly, we assume that from the physiographic perspective, the anthropogenic landscape is a category characterised by significant apparentness. This is reflected well in the above-mentioned interpretation dissonances based on the illusoriness of perception. In reality, not only in this one example, the actual landscape type may be completely different from the one experienced by an observer. Therefore, a selected fragment of the anthropogenic landscape examined in accordance with this approach will in each case become a non-inertial frame in which the assessment (of situation, values, structures) depends on the observer's position.

On the other hand, from the materialistic perspective, the landscape is a real entity. It was formed by real anthropogenic structures on the basis of an interaction with real structures of nature. The anthropogenic landscape in this case is not only a perceived category, but also an interpreted one. Here, the observer obtains information regarding the analysed landscape also from sources other than current observation. We can even assert that the latter is only one of the tools intended to discover the features of a given landscape, while in the physiographic approach perception was the essence of cognition, thus exposing such interpretation to apparentness.

\section{Rural and urban landscapes - what does it mean?}

The example of a rural-urban landscape and the ontological conditions of its creation 
presented in the previous chapter still do not reflect the basic dissonance of the issue which consists in answering the question: what is a rural landscape and what is an urban landscape (Antrop 2004a; von der Dunk et al. 2011; Biegańska, Szymańska 2013). This problem is significant especially when planning suburban areas which experience a clash between the socio-economic impact of the city and the surrounding villages (Whitehand 2005; Gallent, Andersson 2007; Mahon 2007; LeSage, Charles 2008; Qviström 2010; de Smet, Teller 2015). In certain countries, e.g. in Poland, we have an additional element, i.e. the issue of the legal and administrative interpretation of the status of a city and a village (Powe, Shaw 2004; Courtney et al. 2007; Dymitrow 2014).

\section{Urban and rural landscapes}

Deliberations concerning urban and rural landscapes have already had significant achievements (Antrop 2004a; Vos, Meekes 1999; Thompson 2012). When we fully embrace its current assumptions and take into consideration the physicalist (mechanistic) approach proposed in the article, we distinguish the following landscapes:

- an urban landscape,

- a landscape of an urban nature,

- a landscape of a rural nature,

- a rural landscape.

The purpose of these different landscape markers for the here presented argument was to structure our analysis and identify overlaps between different ontological conceptualisations of such spaces. The above-mentioned facts are justified by the fact of widespread urbanisation (Antrop 2004a; Alig et al. 2004; Bertinelli, Black 2004) which as a process "does not take into account" neither administrative borders, nor in many cases (mainly in Eastern and Southern Europe) the guidelines of zoning plans. The demands to "go beyond [traditional divisions]" (Wandl et al. 2014) are natural in this context. In our view, an additional justification is found in the aspect of functionalism as the basic determinant of the progress of urbanisation which is at the same time strongly and directly related to the ontological explanation.
In the article we assume that an urban landscape is a landscape characterised by a relatively high spatial concentration of a non-agricultural built environment and infrastructure together with their inhabitants employed in non-agricultural sectors of the economy. On the other hand, a rural landscape is one underlining agricultural functions in the scope of zoning and the social and occupational structure (e.g. Naveh 2001; Johansen, Nielsen 2012; Myga-Piątek 2012; Primdahl et al. 2013).

\section{Conflicts in the spatial planning of urban and rural landscapes}

Conflicts in the area of planning, resulting from the dual interpretation of the landscape, are almost in every case based on the characteristic spatial game in which the rural and urban landscape types clash (Walker, Fortmann 2003; Antrop 2004b; Molema 2012). In the geographical space this interaction gives rise to different effects and can be interpreted in different ways, with attention paid to characteristic phenomena and reference systems. In the context of spatial planning, the article refers to three of them:

- planning of areas characterised by highly variable landscape types in a relatively small area (the landscape heterogenisation),

- spatial planning in the field of dynamic succession of landscapes typologically different from the existing ones (succession of new functions in the landscape),

- planning within areas whose real landscape type is perceptually contrary to the formal status of that area (logical conflict in the landscape).

Of course, there may be more spatial conflicts within the conceptual contact of urban and rural landscapes. The article points to those which in the opinion of the authors are of key significance, especially in Central and Eastern as well as Southern Europe.

\section{Planning of areas characterised by highly variable landscape types in a relatively small area. Example of an urban-rural landscape in Thessaloniki (Greece)}

The development of a city and its spatial planning undoubtedly evokes associations with an urban landscape. But what happens in the case of 
a crisis, decline or urban shrinkage? As the previous development mechanisms are weakened, or even disappear, the city enters into a state of entropy which is typical especially where the previous urbogenic forces decline and there is a significantly prolonged absence of new ones. The city is then susceptible to the initiation of the so-called "substitute" forms of functional development, the expansion of agricultural functions being the most prominent of them. While in a big city the newly-created agricultural areas are only spots which form a local urban-rural chessboard, in smaller cities it may become a common phenomenon, as was recently described within the concept of urban hibernation (Krzysztofik et. al. 2016).

In the case of Thessaloniki in Greece, the city's entropy was projected by a more general phenomenon, i.e. the state crisis after 2008 which challenged rapidly the status quo and the city's resilience capacity. The case of urban sprawl which is broadly discussed below is also characteristically visible in the eastern growth pattern of the city's suburban development (Thermi), challenging the restoring of landscape's apparentness, "legibility" and in fact sustainability. There, the centrifugal and the earliest centripetal forces, the traditional productive landscape and the abrupt and then paused housing development are challenged towards a new socio-economic equilibrium.

However, in view of our discourse we focus on another aspect, the heterogeneity detected in the pockets of the city's core where the rural nature emerges charged with new cultural and functional needs. In the west, mutations in the Lachanokipi landscape characteristically follow the city's evolution. While till the $19^{\text {th }}$ century the site was cultivated land as part of the peri-urban landscape, the industrialisation from the first quarter of the $20^{\text {th }}$ century transformed the area into the city's core of secondary sector of production, being in parallel a node of transport network. In the last decades after the stop of productive activities and the spreading tendencies of the city, the area consists of a typical brownfield, an in-between fragment, where rural (small family greenhouses of the traditional landscape use) coexists with clearly urban poles, industrial remnants and the newly pressing building system of the city's sprawl to this



Fig. 4. Intra-urban agriculture in the $\mathrm{KIPOS}^{3}$ project in Thessaloniki, Greece.

Source: the authors.

direction, preceding the big crash of economic recession ${ }^{6}$.

In a smaller scale, the "rural" appears also in "pockets" as a recent urban activists' manifestation of the last hopes for green commons, new collectivities and a kind of self-sufficiency (e.g. former military training ground in the west). The most characteristic "rural" common in the city core is the recent experiment, the KIPOS 3 project, urging to rethink urban living experience, under also the municipality's assistance, aiming finally to combine the current need for a new social and ecological infrastructure (Fig. 4).

\section{Spatial planning in the field of a dynamic succession of landscapes typologically different from the existing ones. Example of suburbanisation in the surroundings of Timisoara (Romania)}

While the previous example focused on the interpenetration of patches of urban and rural landscapes, which created a specific chessboard of forms of space use in one of the districts of Thessaloniki, the problem of suburbanisation discussed in this subchapter has a slightly different dimension. Firstly, rural and urban landscape elements do not have such clear-cut borders here.

Based on their agricultural functions, such activities also produce an element typical of a 'rural' landscape, as you also find ecological issues of food production within the 'urban' city. 


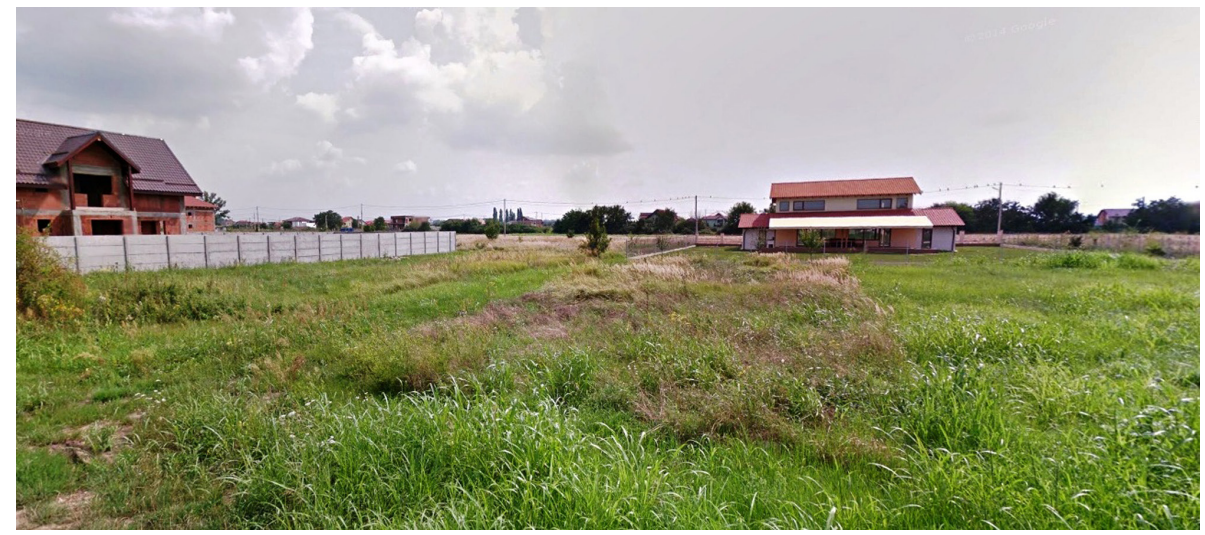

Fig. 5a. Sprawl in the suburban zone of Timisoara in Romania. Dumbrăvita commune. Source: the authors.

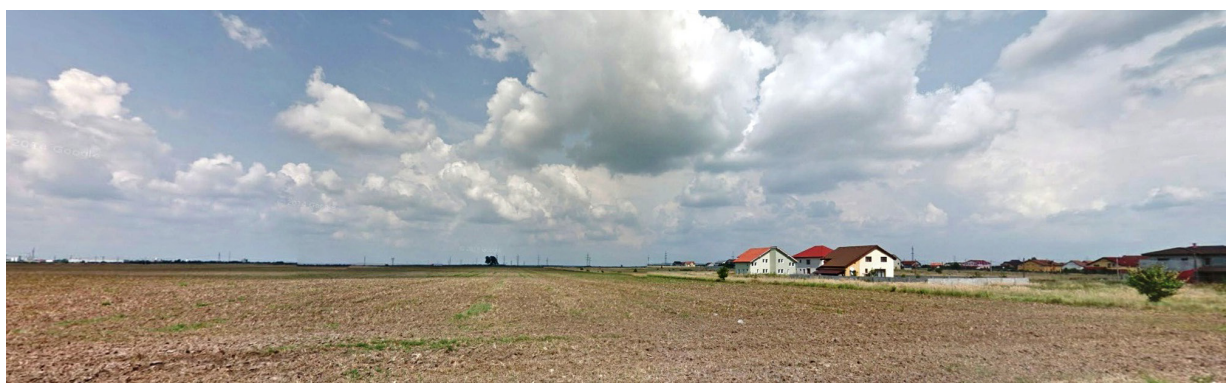

Fig. 5a. Sprawl in the suburban zone of Timisoara in Romania. Sînandrei commune. Source: the authors.

Urban sprawl creates an area which is characterised primarily by temporariness and the lack of horizontal contrasts (Forsyth 2012; Qviström, Cadieux 2012). In the case study we are examining, the concentration of new houses in the suburban area of Timisoara systematically and gradually decreased as the distance from its borders to the main access roads grew. We can see that clearly, e.g. in the case of Dumbrăvita and Sînandrei communes ${ }^{7}$. While the former is characterised by strong suburbanisation which can be described as intensive and expensive, the latter is of extensive nature. In the case of Dumbrăvita, the impact of Timisoara not only causes the urban landscape to occur (Fig. 5), but also characterises the functioning agriculture: there is a significant increase of fallow land and abandoned agricultural areas. There is also a growing pressure and administrative transformation of agricultural land to residential or non-agricultural economic areas. The Sînandrei commune does not experience these

In the years 1992-2015, the population of the Dumbrăvita commune rose by $48 \%$ (from 2.7 thousand in 2000 to 7.5 thousand in 2015) and by $10 \%$ in the Sînandrei commune (from 4.6 thousand in 1992 to 6.8 thousand in 2015). phenomena with such intensity. Urban sprawl gently gives way to previous agricultural functions as we move away from Timisoara. From the ontological perspective, the landscape of both communes is determined by two mechanisms. In the Dumbrovita commune (closer to Timisoara), we have a strong transfer of the function of the region's capital away from it. The centripetal urbogenic forces, which are principal for Timisoara, locate part of their potential outside city borders. On the other hand, in the Sînandrei commune the key role in urban areas is played by centrifugal urbogenic functions related to agriculture and small production. Certainly, administrative borders do not fully coincide with the boundaries of spatial effects of the two impact mechanisms described above. The examples of both presented communes around Timisoara prove that there is a specific struggle in the geographical space and anthropogenic landscape around big cities between two opposing forces: the "offensive" centripetal force and the "defensive" centrifugal force. The size and characteristic features of urban sprawl in the discussed physicalist approach are a direct effect of the intensity and spatial distribution of the impact of those forces. 


\section{Spatial planning and perceptual conflicts between the experienced landscape and the formal status of the area}

The problem discussed in this subchapter may be, to a certain extent, an extreme form of the situation described in the previous case studies. However, such an approach would be a substantial simplification. We should start our considerations from Fig. 6 a-b and $7 a-b$, which are seemingly erroneously described. On the one hand, we are dealing with a strictly urban landscape (Fig. 6a-b) of Pawłowice village in southern Poland (Upper Silesia). On the other hand, we are experiencing a landscape of rural nature (Fig. 7a-b), which absolutely dominates the city of Suraż in north-eastern Poland (Podlasie). Both are model examples of the feature of apparentness in geographical space which is particularly visible at the meeting point of the perception of the anthropogenic landscape and the formal status of the area in which it is located. Although this is particularly viable in countries where the rural-urban distinction finds political (i.e. not merely statistical) reflection, instances of hibernation can also be found elsewhere. This has to do with the fact that the rural-urban distinction is universal, although, in practice, it is resorted to in varying degrees depending on various factors, such as a country's overall level of urbanisation, whether or not the distinction is attained by the legal system, or simply the character of historico-cultural practices present in that particular region. Effectively, despite the diversity of spatial categorisations, throughout Europe, the universality of the rural-urban discourse renders semantic conflicts in spatial planning regardless of whether the national rural-urban distinction is political, statistical or both (Krzysztofik et al. 2016: 319-320).

\section{Spatial planning and the situation of a} perceptual conflict between the experienced landscape and the formal status of the area in which it is located

The contemporary anthropogenic landscape of both localities is formed by the impact of



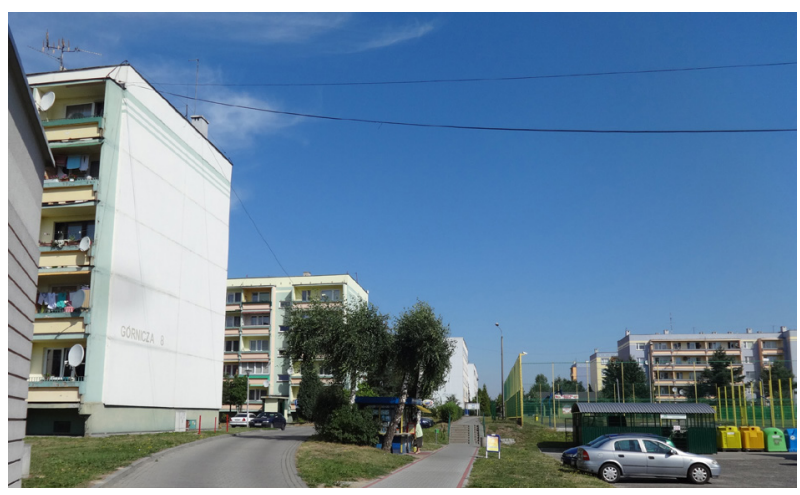

Fig. 6a-b. The "village" of Pawłowice (Silesia, southern Poland). Source: the authors.
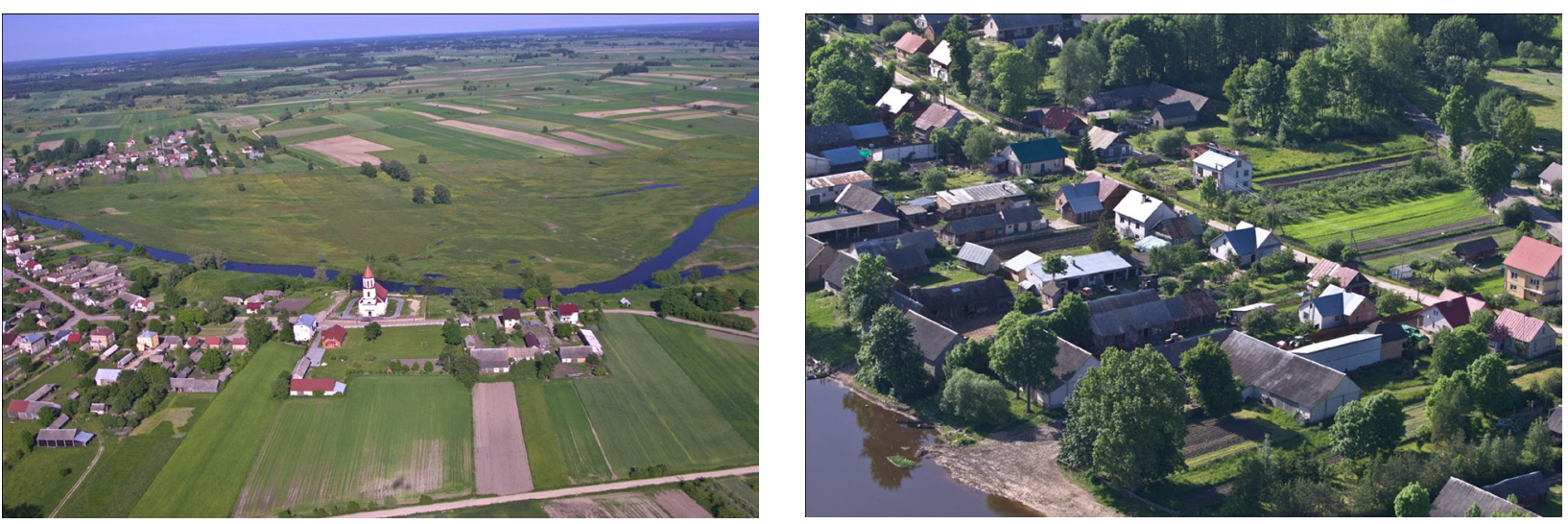

Fig. 7a-b. The "city" of Suraż (north-eastern Poland). Source: photo gallery of the commune of Suraż. 
centrifugal (recoil) forces in the socio-economic system. In the anthropogenic reality, these forces manifest themselves through extremely specialised functions: mining in Pawłowice and agriculture in Suraż. One feature of specialised functions, especially industry and mining, is the primarily quantitative aspect of development. Due to the strong homogenisation of the socio-economic structure, these sectors create only the foundations of urbanisation. It is the attribute of homogeneity in Pawłowice's mining community of 9,000 people, and the lack of other functions which makes us experience a settlement form which may be called a "mining village" rather than a "village" from a formal point of view.

The city of Suraż exemplifies the impact of centrifugal (recoil) forces which ousted the genetic centripetal (gravity) forces. Economically, this change results in strong ruralisation not only of the city's economy, but also of its community and space. The urbogenic basis of administrative and service functions in Suraż should be deemed as apparent as these services are oriented almost exclusively at the locality's population of 1,000. If it was not for the historical traditions of the urbanity of Suraż, dating back to the $15^{\text {th }}$ century, the basic service institutions could well be established in each of the neighbouring villages. This is the primary reason for the apparent urbanity of Suraż, which in the physiognomic and material aspects is a better representation of rural landscape.

\section{Discussion}

In the context of the considerations presented above, including the case studies, we are not able to give an unambiguous answer to the question of whether exclusively urban and rural landscapes are spatial entities. In accordance with the ontological convention we should give a negative answer because we have not only exclusively urban and exclusively rural landscapes, but also those of urban nature and rural nature. Antrop (2004b: 88) defines the above-mentioned anthropogenic landscape types in the following manner: an urban centre, an urban fringe, the rural countryside of the urban network and the "deep" rural. The adopted distinction results from the nature of the operating urbogenic and region-forming forces. As a reminder, in the socio-economic system the rural landscape ("pure") is the effect of the impact exclusively of the recoil force (interpreted also as the centrifugal force). The urban landscape ("pure") is created through the impact of both recoil (centrifugal) forces, and gravity (centripetal) forces.

We are dealing with a different situation in the case of landscapes of an urban or rural "nature", where we assume that primary urbogenic forces, due to their decreasing potential, are overlapped by secondary urbogenic forces. However, the sense of impact of the secondary forces is often opposite to that of the primary forces. This results in the socio-economic and spatial development of two clearly superimposed layers: the one influenced by the forces of gravity and recoil and the one influenced by centripetal and centrifugal forces.

Physicalist explanations leave doubts and uncertainty concerning whether we accurately interpret the typology of the landscape. They may raise the strongest doubts in the case of landscapes which clearly emphasise the impact of apparent forces. Residential suburbs with no clearly distinguished economic function are the most telling example.

Therefore, the standard procedure of determining the nature of the anthropogenic landscape in this case as well as in others should be preceded by an attempt to define the economic functions of the analysed space. Our findings should answer the question regarding the predominant economic source of existence of the anthropogenic space (level 1 in Table 1). Without pointing to the priorities in this field, we conclude that before determining the landscape type in terms of methodology we should determine (level 2a in Table 1 ) the economic functions of space (exogenous functions, endogenous functions, functional specialisation, the structure of regional and trans-regional economic links). When synthesising the functions of the examined space we should ultimately take into account the division into primary and secondary (apparent) functions. At the same epistemological level we need to specify the types of forces which determine the nature of the experienced anthropogenic landscape (level $2 b$ in Table 1). The next step consists in examining the landscape itself, defining it, in this case from the 
Table 1. The place of the physicalist approach in determining the nature of anthropogenic landscape in accordance with the materialistic criterion.

\begin{tabular}{|c|c|}
\hline $\begin{array}{c}\text { Selecting the area to be examined and collecting detailed information regarding the economy in that area (structure } \\
\text { and size of employment, structure and size of companies' revenue, spatial relationships of companies and economic } \\
\text { institutions) }\end{array}$ \\
\hline $\begin{array}{c}\text { Determining economic functions of the region, taking } \\
\text { into account primary and secondary functions }\end{array}$ & $\begin{array}{c}\text { Determining types of forces operating in the geographi- } \\
\text { cal space }\end{array}$ \\
\hline $\begin{array}{c}\text { Determining the type of the anthropogenic landscape: } \\
- \text { urban, rural, } \\
\text { - of urban nature, of rural nature }\end{array}$ & $\begin{array}{c}\text { Determining the scale of the attribute of apparentness } \\
\text { in selected phenomena and elements of spatial develop- } \\
\text { ment }\end{array}$ \\
\hline \multicolumn{2}{|c|}{\begin{tabular}{c} 
Synthesising materialistic approach to anthropogenic landscape \\
\hline Landscape research in accordance with morphological approach
\end{tabular}} \\
\hline Findings in the field of spatial policy and the principles of creating sustainable development in the long run \\
\hline
\end{tabular}

Source: the authors.

point of view of urbanity or rurality (level 3a in Table 1) and determining the role of apparentness in the formation of phenomena and the elements of the geographic space (level $3 \mathrm{~b}$ in Table 1 ).

Such a research procedure helps obtain a relatively real image of the anthropogenic landscape considered in line with the materialistic criterion (level 4 in Table 1). We diagnose structures, components, mechanisms and relation systems. Without those attributes, we would not be able to reliably assess the characteristics of the anthropogenic landscape in connection with the spatial policy and the principles of creating sustainable development in the analysed area (level 6 in Table 1). However, in this case we should simultaneously examine the anthropogenic landscape from the morphological perspective (level 5 in Table 1).

Conflicts in spatial planning are most often a result of similar dilemmas in the local policy. The problems resulting from such conflicts are based on the choice of the most beneficial element or attribute. What needs to be established is for whom it should be the most beneficial and in what scope. If attention is focused on tourist functions in the city development policy, it will certainly strengthen the social perception of the local landscape as urban to a certain extent. However, it may simultaneously lead to the marginalisation of the agriculture and service sectors in that policy. This, in turn, may theoretically perpetuate the process of the city's depopulation and its general socio-economic stagnation.

When we take into consideration the case studies discussed in the article, they generally lead us to an affirmative answer to that question. The defence of "urbanity" against "rurality" manifests itself in Suraż in the creation of urbogenic functions. And although tourist services are preferred over agricultural production, in the end their development has only apparent effects. On the other hand, the illusions created by the rural landscape which occurs in the suburban area of Timisoara are a good counterpoint which reassures us that this area is of non-urban nature. Is it really the case? The example of Pawłowice is more complicated. The local society has decided that it wants to live in a locality which is formally rural (Plucińska 2009). In such case, what exactly is the urban landscape of Pawłowice we experience? Maybe it is one of those "non-Keynesian" expectations of a "Keynesian" illusion of "rural space" (Friedman et al. 2015).

\section{Conclusions}

The anthropogenic landscape is characterised by an increasing diversity, which results primarily from the growing role of urbanisation and, to a lesser extent, from the introduction of rural features into cities. The diversity of the anthropogenic landscape makes it increasingly hard to interpret, particularly in terms of unambiguity.

These difficulties may also be reflected in the spatial policy at the regional or local levels. They manifest themselves primarily by way of "omission" policies and "inadvertently" develop regressive policies. The indicated negative attributes of spatial policy and the principles of creating anthropogenic landscapes are derived, to a large extent, from the lack of recognition of the ontological foundations of phenomena and processes which determine individual areas. 
This article proposes a physicalist approach as one which meets the criteria of a (post-positivist) ontological explanation. In our view, along with the systemic and ecological approaches to landscape research, it is the most beneficial solution. It is relatively easy to apply economic functionalism, which connects detailed geo-economic research and settlement-geography research with the guidelines for the research on the landscape and spatial policies. The physicalism of research on the anthropogenic landscape significantly broadens the interpretative field of the materialistic approach, which we deem preferable to the physiographic approach. The main advantage of the materialistic approach is that it lacks the attribute of "apparentness". It is particularly visible in erroneous planning and political decisions regarding transformations of space and the landscape. Such mistakes are most evident in the places where - instead of the expected sustainable development - we experience development that deepens the negative imbalance. As such, the contribution of this article lies in outlining a coherent ontological framework, in which such discussions can take place.

We propose a research program that focuses on the development of anthropogenic landscapes to be understood from two perspectives regarding the impact of forces that create human settlements:

- firstly, from the perspective which encompasses the fragments of human space which were created directly through the impact of gravitational and recoil forces (often simplified in the scientific literature as centripetal and centrifugal forces); and

- secondly, from the perspective which encompasses genetically secondary elements, which were created on the basis of non-inertial centripetal and centrifugal forces.

We have also underlined that the proper interpretation of which of the above-mentioned forces is responsible for creating the individual elements of the anthropogenic landscape - is fundamental to an accurate diagnosis of the transformative mechanisms of a geographical reality. We stress it is crucial for the development of the sustainable spatial policy.

This article is a first attempt to introduce physicalist ontology onto the concept of anthropogenic landscape. It omits a number of significant issues which require further research, as well as those which were only preambled due to the limited scope of this article (primarily in the field of methodology). Nevertheless, it forms a starting point for the development of the physicalist approach in the mechanistic convention, with respect not only to research on anthropogenic landscapes, but to landscape science in general.

\section{Acknowledgements}

The Greek case study was conducted and presented at the PECSRL 2014 thanks to IKY fellowships of excellence for postgraduate studies in Greece, a 2013-2015 Siemens Program, in the context of the Joint Postgraduate Master Program in Landscape Architecture, School of Agriculture and School of Architecture, Aristotle University of Thessaloniki (A.U.Th.), Greece. The Thermi area was studied as the theme of the design studio "Planning and Design of suburban, rural and natural landscapes", supervised by Prof. Agriculturist-Landscape Architect, Dep. Head of Postgraduate Program in Landscape Architecture (A.U.Th.) Ioannis A. Tsalikidis. The Lachanokipi area was studied as the theme of the design studio "Architectural Design and Landscape" by: Prof. Architect (A.U.Th) Sarantis G.Z. Zafeiropoulos and Prof. emeritus Architect (Jade Hochschule, Oldenburg) Holm Kleinmann. The KIPOS $^{3}$ project is the first common garden in Thessaloniki and started in 2014 as the initiative of Eleftheria Gavriilidou, Eleni Oureilidou and Maria Ritou, supported by the Angelopoulos GIU Fellowship 2014, the Ambassador Mrs. Gianna Angelopoulos Daskalaki and the Municipality of Thessaloniki.

\section{References}

Alig R.A., Kline J.D., Lichtestein M., 2004. Urbanization on the US landscape: Looking ahead in the $21^{\text {st }}$ century. Landscape and Urban Planning 69(2-3): 219-234.

Antrop M., 2004a. Landscape change and the urbanization process in Europe. Landscape and Urban Planning 67(1-4): 9-26.

Antrop M., 2004b. Rural-urban conflicts and opportunities. In: Jongman R.H.G. (ed.), The new dimensions of the European landscapes. Kluwer Academic Publishers, Dordrecht: 83-91.

Bański J., 2006. Geografia wsi. PWN, Warsaw.

Berger P.L., Luckmann T., 1966. The social construction of reality. Anchor Books, Garden City, NY. 
Bertinelli L., Black D., 2004. Urbanization and growth. Journal of Urban Economics 56(1): 80-96.

Biegańska J., Szymańska D., 2013. The scale and the dynamics of permanent migration in rural and peri-urban areas in Poland - some problems. Bulletin of Geography. Socio-economic Series 21: 21-30.

Biegańska J., Dymitrow M., Grzelak-Kostulska E., 2014 Under urban mask: On rural landscapes with different logics. Special session at the 26th Permanent European Conference on the Study of the Rural Landscape - "Unraveling the logics of landscape", 8-12 September 2014, Gothenburg, Sweden.

Bossuet L., 2006. Peri-rural populations in search of territory. Sociologia Ruralis 46: 214-28.

Brabyn L., 2009. Classifying landscape character. Landscape Research 34(3): 299-321.

Brauer R., Dymitrow M., 2017. Human geography and the hinterland: The case of Torsten Hägerstrand's 'belated' recognition. Moravian Geographical Reports 25(2): 74-84.

Brenner N., 2013. Theses on urbanization. Public Culture 25(1): 85-114.

Cavallo A., Di Donato B., Marino D., 2016. Mapping and assessing urban agriculture in Rome. Agriculture and Agricultural Science Procedia 8: 774-783.

Champion A., Hugo G., 2004. New forms of urbanization: Beyond the urban-rural dichotomy. Ashgate, Aldershot.

Cloke P., Johnston R., 2005. Deconstructing human geography's binaries. In: Cloke P., Johnston R. (eds), Spaces of geographical thought: Deconstructing human geography's binaries. Sage, Thousand Oaks and New Dehli, London: 1-20.

Connell J., 2016. Soft country? Rural and regional Australia in country style. In: Dufty-Jones R., Connell J. (eds), Rural Change in Australia: Population, Economy, Environment. Routledge, London/New York: 211-234.

Cosgrove D., 1984. Prospect, perspective and the evolution of the landscape idea. Transactions of the Institute of British Geographers 10(1): 45-62.

Courtney P., Mayfield L., Tranter R., Jones P., Errington A., 2007. Small towns as 'sub-poles' in English rural development: Investigating rural-urban linkages using sub-regional social accounting matrices. Geoforum 38(6): 1219-1232.

Daniels S., 1989. Marxism, culture, and the duplicity of landscape. In: Richard P., Nigel T. (eds), New models in geography, 2. Unwin Hyman, London: 196-220.

de Groot R., 2006. Function-analysis and valuation as a tool to assess land use conflicts in planning for sustainable, multifunctional landscapes. Landscape and Urban Planning 75(3-4): 175-186

de Smet F., Teller J., 2015. Characterising the morphology of suburban settlements: A method based on a semi-automatic classification of building clusters. Landscape Research 41(1): 113-130.

Deng J.S., Wang K., Hong Y., Qi J.G., 2009. Spatio-temporal dynamics and evolution of land use change and landscape pattern in response to rapid urbanization. Landscape and Urban Planning 92(3-4): 187-198.

Drexler D., 2013. Landscape, Paysage, Landschaft, Táj: The cultural background of landscape perceptions in England, France, Germany, and Hungary. Journal of Ecological Anthropology 16(1): 85-96.

Duncan J.S., Duncan N.G., 2001. The aestheticization of the politics of landscape preservation. Annals of the Association of American Geographers 91(2): 387-409.
Dymitrow M., Brauer R., 2016. Land or people? On the iatrogenesis of conflation. Acta Geobalcanica 2/2: 63-75.

Dymitrow M., 2013. Degraded towns in Poland as cultural heritage. International Journal of Heritage Studies 19(7): 613-631.

Dymitrow M., 2014. The effigy of urbanity or a rural parody? A visual approach to small-town public space. Journal of Cultural Geography 31, 1-31.

Dymitrow M., Biegańska J., Grzelak-Kostulska E., 2017. Deprivation and the rural-urban trap. Tijdschrift voor economische en sociale geografie.

Dymitrow M., Stenseke M., 2016. Rural-urban blurring and the subjectivity within. Rural Landscapes: Society, Environment, History 3(1) 4: 1-13.

Forsyth A., 2012. Defining suburbs. Journal of Planning Literature 27(3): 270-281.

Friedman B., Krugman P., Skidelsky R., 2015. Economics after the crash: A discipline in need of renewal? Scandinavia House, New York.

Fujita M., Krugman P., Venables A.J., 2001. The spatial economy. Cities, regions, and the international trade. The MIT Press, Cambridge-London.

Fujita M., 2012. Thünen and the new economic geography. Regional Science and Urban Economics 42(6): 907-912.

Fujita M., Thisse J.F., 2002. Economies of agglomeration. Cities, industrial location, and regional growth. Cambridge University Press, Cambridge.

Gobster P.H., Nassauer J.I., Daniel T.C., Fry G., 2007. The shared landscape: What does aesthetics have to do with ecology? Landscape Ecology 22(7): 959-972.

Gregory D., Johnston R., Pratt G., Watts M., Whatmore S. (eds), 2009. The dictionary of human geography. Wiley-Blackwell Publishing.

Gallent N., Andersson J., 2007. Representing England's rural-urban fringe. Landscape Research 32(1): 1-21.

Guba E.G., Lincoln Y.S., 1994. Competing paradigms in qualitative research. In: Denzin N.K., Lincoln Y.S. (eds), Handbook of qualitative research 2: 163-194. Sage, Thousand Oaks, CA, London, New Delhi: 105-117.

Halfacree K.H., 1993. Locality and social representation: Space, discourse and alternative definitions of the rural. Journal of Rural Studies 9(1): 23-37.

Halfacree K.H., 2009. Rurality and post-rurality. In: Kitchin R., Thrift N. (eds), International encyclopedia of human geography (Volume I). Elsevier, London: 449-456.

Hartshorne R., 1939. The nature of geography: A critical survey of current thought in the light of the past. The Association Lancaster, Lancaster, PA.

Henderson G.L., 2003. What (else) we talk about when we talk about landscape: For a return to the social imagination. In: Wilson Ch., Groth P. (eds), Everyday America: cultural landscape studies after J.B. Jackson. University of California Press, Berkeley, CA: 178-198.

Hoggart K., 1990. Let's do away with rural. Journal of Rural Studies 6(3): 245-257.

Hubbard P., 2006. City. Routledge, Abingdon and New York.

Hubbard P., Kitchin R., Bartley B., Fuller D., 2002. Thinking geographically: space, theory and contemporary human geography. Continuum, London, New York.

Jaynes E.T., 2003. Probability theory: The logic of science. Cambridge University Press, Cambridge.

Johansen P.H., Nielsen N.Ch., 2012. Bridging between the regional degree and the community approaches to rurality - A suggestion for a definition of rurality for everyday use. Land Use Policy 29(4): 781-788. 
Jones M., Stenseke M., 2011. The issue of public participation in the European landscape convention, In: Jones M., Stenseke M. (eds), The European landscape convention. Challenges of participation. Springer Science, Dordrecht, Heidelberg, London, New York: 1-23.

Knudsen J.M., Hjorth P.G., 1996. Elements of Newtonian Physics. Including Nonlinear Dynamics. Springer, Berlin, Heidelberg.

Krugman P., 1995. Urban concentration: The role of increasing returns and transport costs. In: Proceedings of the World Bank Annual Conference on Development Economics. The World Bank: 241-263.

Krzysztofik R., 2014. Geneza aglomeracji miast na obszarze Polski. University of Silesia Publishing House, Katowice.

Krzysztofik R., 2016. Revisited question of centripetal and centrifugal forces in urban systems. Geographia Polonica 89(4): 429-442.

Krzysztofik R., Dymitrow M., Kantor-Pietraga I., Spórna T., 2016. Concept of urban hibernation. European Planning Studies 24(2): 316-343.

LeSage J.P., Charles J.S., 2008. Using home buyers' revealed preferences to define the urban-rural fringe. Journal of Geographical Systems 10(1): 1-21.

Lincoln Y.S., Lynham S.A., Guba E.G., 2011. Paradigmatic controversies, contradictions, and emerging confluences, revisited. In: Denzin N.K., Lincoln Y.S. (eds), The SAGE Handbook of Qualitative Research 4. Sage, Los AngelesWashington DC: 97-128.

Mahon M., 2007. New populations; shifting expectations: The changing experience of Irish rural space and place. Journal of Rural Studies 23(3): 345-356.

Martin R.L., Sunley P., 2012. Forms of emergence and the evolution of economic landscape. Journal of Economic Behavior \& Organization 82(2-3): 338-351.

Masuda J.R., Garvin T., 2008. Whose heartland? The politics of place in a rural-urban interface. Journal of Rural Studies 24(1): 112-123.

Mazzochi C., Sali G., Corsi S., 2013. Land use conversion in metropolitan areas and the permanence of agriculture: Sensitivity Index of Agricultural Land (SIAL), a tool for territorial analysis. Land Use Policy 35: 155-162.

Mels T., Germundsson T., 2013. Figures in the revolutionary landscape: An introduction. Geografiska Annaler: Series B, Human Geography 95: 213-218.

Millward H., Harrington L., Ilbery B., Beesley K., 2003. Milieux, viewpoints, and processes of change in the new countryside. In: Beesley K., Millward H., Harrington L. (eds), The new countryside: Geographic perspectives on rural change. Brandon University, Brandon: 9-23.

Mitchell D., 2002. Cultural landscapes: The dialectical landscape - recent landscape research in human geography. Progress in Human Geography 26(3): 381-389.

Molema M., 2012. The urban west and the rural rest: Framing in Dutch regional planning in the 1950s. Landscape Research 37(4): 437-450.

Mormont M., 1990. Who is rural? Or, how to be rural: Towards a sociology of the rural. In: Marsden T., Lowe P., Whatmore S. (eds), Rural restructuring. Global processes and their responses. David Fulton Publishers, London: 21-44.

Moseley M.J., 2003. Rural development: Principles and practice. SAGE Publications Limited, London.

Myga-Piątek U., 2012. Krajobrazy kulturowe. Aspekty ewolucyjne i typologiczne. University of Silesia Publishing House, Katowice.
Naveh Z., 2001. Ten major premises for a holistic conception of multifunctional landscapes. Landscape and Urban Planning 57(3-4): 269-284.

Nefedova T., Pallot J., 2013. The multiplicity of second home development in the Russian Federation: A case of seasonal suburbanization. In: Roca Z. (ed.), Second home tourism in Europe: Lifestyle issues and policy responses. Routledge, London, New York: 91-121.

Olsen J., 2002. On the units of geographical economies. Geoforum 33(2): 153-164.

Olwig K.R., 1996. Recovering the substantive nature of landscape. Annals of the Association of American Geographers 86(4): 630-653.

Plucińska S., 2009. Pawłowice nie chcą być miastem. Dziennik Zachodni 27.07.2009. <http://www.dziennikzachodni.pl/artykul/146111, pawlowice-nie-chca-byc-miastem,id,t.html> 18.01.2017.

Powe N.A., Shaw T., 2004. Exploring the current and future role of market towns in servicing their hinterlands: A case study of Alnwick in the North East of England. Journal of Rural Studies 20(4): 405-418.

Prové C., Dessein J., De Krom M., 2016. Taking context into account in urban agriculture governance: Case studies of Warsaw (Poland) and Ghent (Belgium). Land Use Policy 56: $16-26$.

Primdahl J., Andersen E., Swaffield S., Kristensen L., 2013. Intersecting dynamics of agricultural structural change and urbanisation within european rural landscapes: Change patterns and policy implications. Landscape Research 38(6): 799-817.

Qviström M., 2010. Shadows of planning: On landscape/ planning history and inherited landscape ambiguities at the urban fringe. Geografiska Annaler: Series B 92(3): 219-235.

Qviström M., Cadieux K.V., 2012. Spatial order, scenic landscapes and sprawl: Peri-urban studies at the interface between landscape and planning history. Landscape Research 37(4): 395-398.

Richling A., Solon J., 2011. Ekologia krajobrazu (Landscape ecology). PWN, Warszawa.

Rose G., 1993. Feminism and geography: The limits of geographical knowledge. Polity Press, Cambridge, Malden, MA.

Sauer C.O., 1925. The morphology of landscape. University of California Publications in Geography 2(2): 19-54.

Smart J.J.C., 1959. Sensations and brain processes. The Philosophical Review 68(2): 141-156.

Smithers J., Joseph A.E., Armstrong M., 2005. Across the divide (?): Reconciling farm and town views of agriculture-community linkages. Journal of Rural Studies 21(3): 281-295.

Somerville P., Halfacree K., Bosworth G., 2014. Interrogating rural coherence (Conclusion). In: Bosworth G., Somerville P. (eds), Interpreting rurality: Multidisciplinary approaches. Routledge, London, New York: 278-296.

Taylor N., 2007. Urban planning theory since 1945. Sage Publications Ltd., London.

Thompson I.H., 2012. Ten tenets and six questions for landscape urbanism. Landscape Research 37(1): 7-26.

Tornaghi Ch., 2014. Critical geography of urban agriculture. Progress in Human Geography 38(4): 551-567.

Tribe J., Liburd J.J., 2016. The tourism knowledge system. Annals of Tourism Research 57: 44-61.

Tunströ M., Smas L., 2017. Spänningar på ett fält - stadsplaneringens diskurs och praktik på gränsen mellan innerstad och förort. Ymer 137: 145-164. 
Tveit M., Ode Å., Fry G., 2006. Key concepts in a framework for analysing visual landscape character. Landscape Research 31(3): 229-255.

Ulied A., Biosca O., Rodrigo R., 2010. Urban and rural narratives and spatial development trends in Europe. Mcrit SL, Barcelona.

Walker P., Fortmann L., 2003, Whose landscape? A political ecology of the 'exurban' Sierra. Cultural Geographies 10(4): 469-491.

Vaishar A., Zapletalová J., Nováková E., 2016. Between urban and rural: Sustainability of small towns in the 21 Czech Republic. European Countryside 8(4): 351-372.

von der Dunk A., Gret-Regamey A., Dalang T., Hersperger A.M., 2011. Defining a typology of peri-urban land use conflicts - A case study from Switzerland. Landscape and Urban Planning 101(2): 149-156.

Vos W., Meekes H., 1999. Trends in European cultural landscape development: Perspectives for a sustainable future. Landscape and Urban Planning 46(1-3): 3-14.
Wand D.I.A., Nadin V., Zonnenveld W., Rooij R., 2014. Beyond urban-rural classifications: Characterising and mapping territories-in-between across Europe. Landscape and Urban Planning 130: 50-63.

Ward N., Brown D.L., 2009. Placing the rural in regional development. Regional studies 43(10): 1237-1244.

Whitehand J., 2005. Urban morphology, urban landscape and fringe belts. Urban Design 93: 19-21.

Woods M., 2009. Rural geography: Blurring boundaries and making connections. Progress in Human Geography 33(6): 849-858.

Woods M., 2010. Rural. Routledge, Abingdon, New York.

Wu F., Zhang F., Webster C., 2013. Informality and the development and demolition of urban villages in the Chinese peri-urban area. Urban Studies 50(10): 1919-1934.

Wylie J., 2007. Landscape. Routledge, London.

Xin S., Tribe J., Chambers D., 2013. Conceptual research in tourism. Annals of Tourism Research 41: 66-88. 